\title{
シマトビケラ属幼虫のストレス応答物質の 個体サイズによる違いと季節変化
}

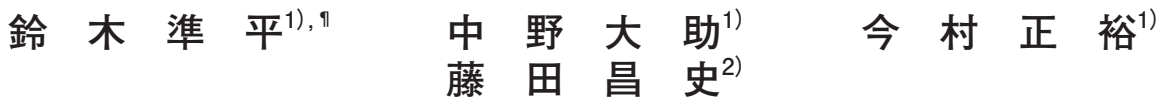

\section{Change in Oxidative Stress Biomarkers in Stream Caddisfly, Hydropsyche spp., Larvae Depending on Size and Season}

\author{
Jumpei SUZUKI ${ }^{1), ", ~ D a i s u k e ~ N A K A N O ~}{ }^{1)}$, Masahiro IMAMURA ${ }^{\text {1) }}$ and Masafumi FUJITA ${ }^{2)}$ \\ 1) River and Coastal Environment Sector, Central Research Institute of Electric Power Industry, 1646 Abiko, Abiko, Chiba 270-1194, Japan \\ 2) Department of Civil, Architectural and Environmental Engineering, Graduate School of Science and Engineering, Ibaraki University, \\ 4-12-1 Nakanarusawa, Hitachi, Ibaraki 316-8511, Japan
}

\begin{abstract}
Extensive marine environment monitoring has been performed using oxidative stress biomarkers. However, progress regarding the use of these biomarkers in river environment monitoring has been insufficient. When applying oxidative stress biomarkers in river aquatic organisms, it is important to take into consideration the natural fluctuation of these markers. In this study, we investigate the effect of body size and seasonal changes on oxidative stress biomarkers in stream caddisfly, Hydropsyche spp., which is one of the primary consumers in river ecosystems. Body sizes were classified into 4 classes in accordance with wet weight. Catalase activity, which is a type of antioxidant enzyme, tended to differ depending on the class. Catalase activity and the oxygen radical absorbance capacity had a significant correlation with wet weight. On the other hand, examining the seasonal change for the same size class, the catalase activity, oxygen radical absorbance capacity, and oxidative damage showed different responses. Furthermore, Hydropsyche spp. in August, in a survey conducted immediately after a flood, indicated low oxidative damage. Hydropsyche spp. was able to adequately remove the reactive oxygen species produced as a result of stress caused by the flood.
\end{abstract}

Keywords: Body size; Seasonal change; Hydropsyche; Oxidative stress

\section{1.はじめに}

污染物質のモニタリングやその影響評価を目的として， ストレスに応答する生物体内物質（ストレスバイオマー カー）を用いた研究が数多く行われている ${ }^{1,2)}$ 。これらの 手法は，海域生物への適用事例が多い去。一方で，河川 への適用例は少なく, 中でも河川生態系における一次消 費者として位置づけられる水生昆虫についての研究は限 られており，例えばSala et al. (2016) がシマトビケラ属 の 1 種 (Hydropsyche exocellata) を対象に塩化物イオン および硫酸イオンに対する応答を調べた研究5) やPradhan et al. (2016) が携巣型トビケラ (Allogamus ligonifer) を対象に銅ナノ粒子に対する応答を調べた研究6) のほか は，ほとんど研究がなされておらず，情報が不足してい る。また, 自然由来の擋乱が大きな河川環境中 ${ }^{7)}$ におい て同手法を適用させる場合には, 季節変動がストレスバ イオマーカーに与える影響を把握することが重要である。
また，生物は，その成長段階によって污染物質などの 環境変動に対する影響の感受性や適応能力に違いが生じ ることが知られており ${ }^{8,9)}$ ， ストレスバイオマーカーにつ いても，成長段階によってその応答が異なる可能性が高 い。例えば，異なる成長段階のゼブラフィッシュに農薬 の 1 種であるジフェノコナゾールを曝露した際に，ス卜 レスバイオマーカーの1つであるカタラーゼ (CAT) や 過酸化脂質 (LPO) の応答が異なることが報告されてい る ${ }^{10)}$ 。また, Ahmad et al., (2011) は，異なる年齢の二 枚貝 (Scrobicularia plana) に対して水銀を曝露した際 にも，2 年目の個体と比較して，3 年目および 5 年目の個 体の方が CAT, LPO が有意に高い值を示すことが報告さ れている ${ }^{11)}$ 。同様に河川の水生昆虫においても成長とと もに，ストレスバイオマーカーの量が変化すると考える。 そこで本研究では，河川底生生物のうち，日本全国に 分布がみられる造網型の水生昆虫であるシマトビケラ属 (Hydropsyche spp.) 幼虫を対象として，まず成長段階と

1）一般財団法人電力中央研究所水域環境領域 †270-1194 千葉県我孫子市我孫子 1646

2 ) 茨城大学大学院理工学研究科都市システム工学領域 †316-8511 茨城県日立市中成沢町 4-12-1

ๆ連絡先 : jumpei@criepi.denken.or.jp 
して湿重量に応じて分類したクラスとストレスバイオマ 一カーとの関係を調べた。そして，異なる時期に（2月， 5 月，8月，10月）に採取したシマトビケラについて調 ベることで，ストレスバイオマーカーの季節変化を明ら かにすることを目的とした。

\section{2. 方法}

\section{1 サンプルの採取}

サンプルの採取は, 埼玉県北西部の小鹿野町を流れる 赤平川 $\left(\mathrm{N} \mathrm{36} 6^{\circ} 0^{\prime} 56^{\prime \prime}, \mathrm{E} 139^{\circ} 0^{\prime}\right.$ 16" $\left.^{\prime \prime}\right)$ において 2016 年 2 月 26 日， 5 月 25 日， 8 月 28 日， 10 月 14 日に行った。 赤平川の流域面積は, 流域面積 $123.6 \mathrm{~km}^{2}$ であり, その 土地利用割合は森林が $88.7 \%$, 耕作地が $6.3 \%$, 住宅地が $2.3 \%$ と森林が大部分を占める流域である（国土交通省国 土政策局国土情報課 国土数值情報 平成 26 年土地利用細 分メッシュデータ)。赤平川流域の雨量（気象庁アメダス デー夕，秩父）および水位（秩父県土整備局，小判沢） の 1 時間毎の時系列デー夕を Fig. 1 に示す。2016 年 2 月 26 日，5月 25 日，10月 14 日におけるサンプルの採取は, コドラート付きサーバーネットによる定量サンプリング （各箇所の採取面積 $=0.063 \mathrm{~m}^{2}, 9$ 箇所）を行い, 生息密
度，現存量およびストレスバイオマーカー用のサンプル とした。ただし，定量サンプリングにて十分な個体数を 得ることが出来なかった，10月 14 日については，定性 サンプリングも行い各分析用のサンプルを採取した。サ ンプリングは, 平均流速 $67.2 \pm 20.3 \mathrm{~cm} \mathrm{~s}^{-1}$ かつ平均水深 $12.3 \pm 2.8 \mathrm{~cm}$ の瀬を対象に行った。 8 月 28 日は出水直後 であり流量が大きく，定量サンプリングができなかった ため, 上記の物理条件外となる岸際での定性サンプリン グのみによりサンプルを採取した。また，サンプル採取 時に, プロペラ式流速計 (Kenek VR-301, VR3T-2-20N) および折れ尺を用いて横断的に測定した流速および水深 から算出した流量および簡易水質観測装置（Hydrolab MS5）で計測した水質と $0.45 \mu \mathrm{m}$ のメンブランフィルタ 一でろ過した河川水中の 3 態窒素濃度（イオンクロマト 法）を Table 1 に示す。ただし， 2 月 26 日と 5 月 25 日 については，簡易水質観測装置による測定が行えなかっ たため, 測定日が最も近い 2 月 18 日および 5 月 24 日の 值を示す。

採取したサンプルは, 現地にてドライアイスにて即座 に凍結して実験室に持ち帰り，分析まで-80 ㄷで保存した。

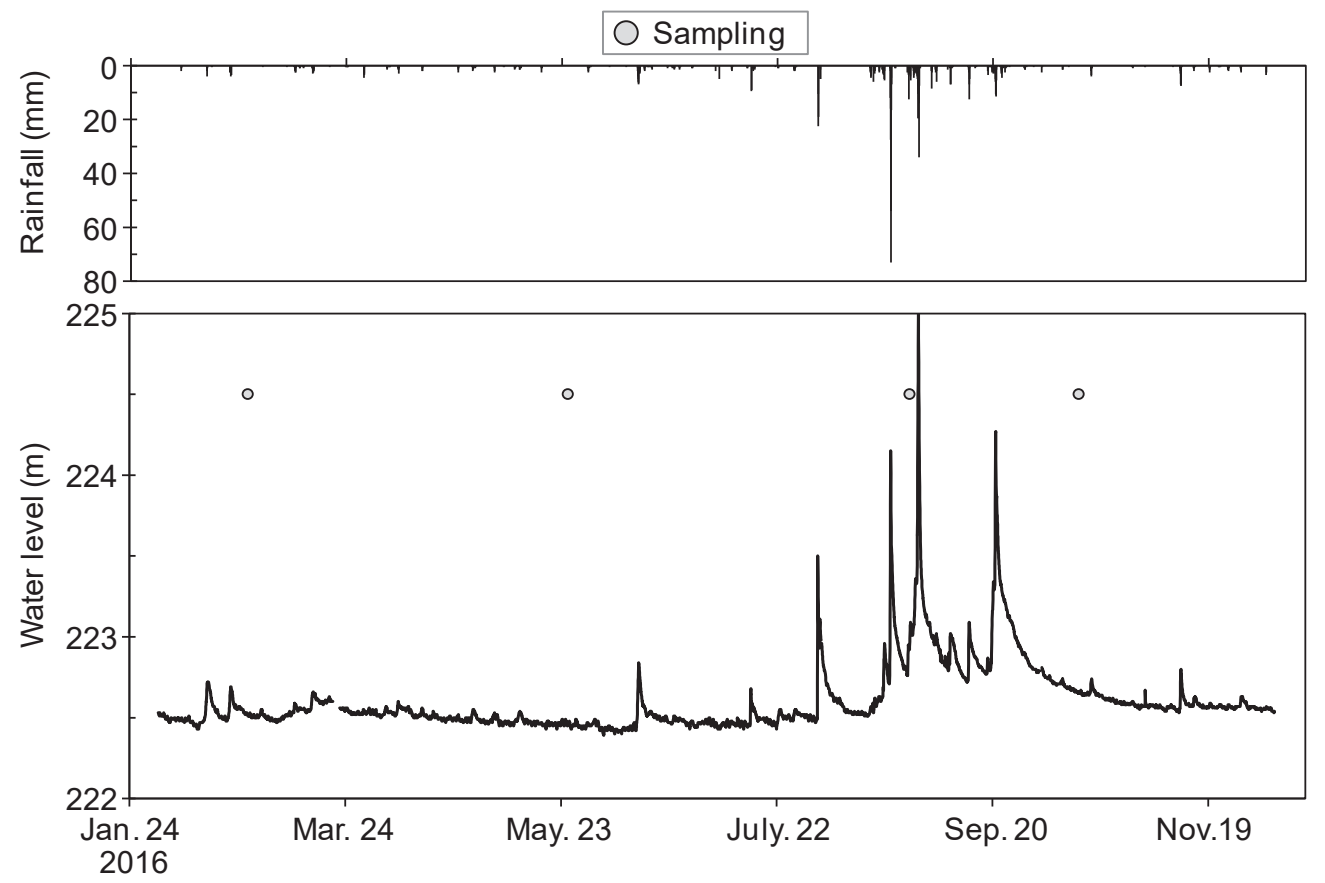

Fig. 1 Time course of rainfall at Chichibu and water level at Kobanzawa in Akahira river.

Table 1 Discharge and water quality of Akahira river.

\begin{tabular}{|c|c|c|c|c|c|c|c|c|}
\hline Date & $\begin{array}{c}\text { Discharge } \\
\mathrm{m}^{3} \mathrm{~s}^{-1}\end{array}$ & $\begin{array}{c}\text { Water Temperature } \\
{ }^{\circ} \mathrm{C} \\
\end{array}$ & $\begin{array}{c}\mathrm{EC} \\
\mu \mathrm{S} \mathrm{cm}{ }^{-1}\end{array}$ & $\begin{array}{c}\mathrm{DO} \\
\mathrm{mg} \mathrm{L}^{-1}\end{array}$ & $\begin{array}{l}\text { Chl.a } \\
\mu \mathrm{g} \mathrm{L}^{-1}\end{array}$ & $\begin{array}{c}\mathrm{NH}_{4} \\
\mathrm{mg}-\mathrm{N} \mathrm{L}^{-1}\end{array}$ & $\begin{array}{c}\mathrm{NO}_{2} \\
\mathrm{mg}-\mathrm{NL}^{-1}\end{array}$ & $\begin{array}{c}\mathrm{NO}_{3} \\
\mathrm{mg}-\mathrm{NL}^{-1}\end{array}$ \\
\hline $2016 / 2 / 18$ 15:20 & 0.31 & 5.9 & 175.4 & 11.9 & $\mathrm{ND}^{*}$ & 0.0 & 0.0 & 8.0 \\
\hline $2016 / 5 / 24$ 16:20 & 0.45 & 21.4 & 213 & 8.6 & 1.5 & 0.0 & 0.0 & 3.4 \\
\hline 2016/8/28 16:20 & 5.09 & 19.0 & 141.1 & 8.5 & 1.2 & 0.0 & 0.0 & 6.7 \\
\hline $2016 / 10 / 14$ 15:00 & 1.75 & 17.0 & 163.9 & 9.9 & 1.1 & 0.0 & 0.0 & 3.1 \\
\hline
\end{tabular}




\section{2 サンプルの処理}

採取したサンプルは, 吸水ろ紙で体表面の水分を拭き 取った後, 電子天科を用いて湿重量を測定した。最も湿 重量の小さかった $6.6 \mathrm{mg}$ を基準とした $6 \mathrm{mg}$ 以上から 6 $\mathrm{mg}$ ずつクラス分けを行い, $6 \mathrm{mg}$ 以上 $12 \mathrm{mg}$ 未満, 12 $\mathrm{mg}$ 以上 $18 \mathrm{mg}$ 未満, $18 \mathrm{mg}$ 以上 $24 \mathrm{mg}$ 未満, $24 \mathrm{mg}$ 以 上の 4 つのクラスに分類した。湿重量を測定した後, Pradhan et al. (2016) の方法と同様に頭部のみを切除し, 体部を分析に使用した ${ }^{6)}$ 。体部は, $10 \mathrm{mmol} \mathrm{L}^{-1}$ トリスヒ ドロキシメチルアミノメタン溶液および $1 \mathrm{mmol} \mathrm{L}^{-1}$ EDTA を混合した TE バッファー $(\mathrm{pH} \mathrm{8.0)} 1 \mathrm{~mL}$ 中で ホモジナイズした。ホモジナイズしたサンプルのうち, $200 \mu \mathrm{L}$ は, 後述する LPO 分析のため, 別の容器に移し $-80{ }^{\circ} \mathrm{C}$ で保存した。残りのホモジナイズサンプルは, 遠 心分離 $\left(10000 \times \mathrm{g}, 4{ }^{\circ} \mathrm{C}, 10 \mathrm{~min}\right)$ し, 得られた上澄液を タンパク, CAT, 総抗酸化力 (ORAC) の分析試料とした。

\section{3 ストレスバイオマーカーの評価}

以下に，タンパクおよびストレスバイオマーカーであ る CAT, ORAC, LPO の分析方法を示した。

\subsection{1 タンパク}

溶解性タンパクの分析は, Bradford 法により行い ${ }^{12)}$, 10 倍希釈した上澄み試料 $10 \mu \mathrm{L}$ に CBB 溶液（ナカライ テスク） $190 \mu \mathrm{L}$ を加え, 10 分間振盪した。その後, 25 ${ }^{\circ} \mathrm{C}$ で 10 分間静置し, マイクロプレートリーダ (TECAN, infinite F200PRO）を用いて測定波長 $595 \mathrm{~nm}$ で吸光度 を測定した。標準物質にはウシ血清アルブミン（Wako, ウシ血清由来 脂肪酸/ IgG/プロテアーゼ不含 生化学用) を用いた。

\section{3.2 カタラーゼ (CAT)}

$\mathrm{CAT}$ は, 体内で生成される $\mathrm{H}_{2} \mathrm{O}_{2}$ を $\mathrm{H}_{2} \mathrm{O}$ に変換する抗 酸化酵素の 1 つである ${ }^{13)}$ 。体内において $\mathrm{H}_{2} \mathrm{O}_{2}$ 自身は, 酸 化力が強くないものの, 鉄などの遷移金属の存在化で最 も酸化力の強いヒドロキシラジカルに変換され, 脂質や タンパクにダメージを与えることが知られている ${ }^{14)} 。 そ$ の前段階で酸化物質を抑制する CAT は，重要な役割を 担う酵素の 1 つである。CAT の分析は, Cohen (1970) を参考に，以下の方法で行った ${ }^{13)}$ 。

$25{ }^{\circ} \mathrm{C}$ にた 100 mM PBS (pH7.0) $100 \mu \mathrm{L}$ に 10 倍希 釈した上澄み試料 $10 \mu \mathrm{L}$ を添加し, $30 \mathrm{sec}$ 振盪した。そ の後, $25{ }^{\circ} \mathrm{C}$ に保った過酸化水素水 $(75.6 \mathrm{mM})$ を $100 \mu \mathrm{L}$ 添加後, $5 \mathrm{sec}$ 振盪し, マイクロプレートリーダを用い

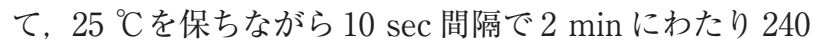
$\mathrm{nm}$ で吸光度を測定した。標準物質には, ウシ肝臓由来 カタラーゼ (Wako, 生化学用) を用いた。

\subsection{3 総抗酸化力 (ORAC)}

ORAC は, ヒドロキシラジカルなどの活性酸素種 （ROS）が細胞内物質と反応することによって生じた脂質 ペルオキシラジカルを含むアルキルペルオキシラジカル を除去する抗酸化物質の総量を測定するものである ${ }^{15)}$ 。 そのため, ORAC は, 水生生物の酸化ストレスに対する 感受性や還元状態を表す指標とされている ${ }^{15)}$ 。ORAC は, 以下に示す方法で分析した ${ }^{16)}$ 。

10 倍希釈した上澄み試料 $10 \mu \mathrm{L} に 100 \mathrm{mM}$ PBS $(\mathrm{pH}$ 7.2）に溶解したフルオレセイン（600 nM）を $160 \mu \mathrm{L}$ 添 加し, $30 \mathrm{sec}$ 振盪した。その後, ラジカル開始剤 $\mathrm{AAPH}$ （100 mM）を $30 \mu \mathrm{L}$ 添加後, 再び $30 \mathrm{sec}$ 振盪し, マイ
クロプレートリーダを用いて, $37{ }^{\circ} \mathrm{C}$ 保ちながら $3 \mathrm{~min}$ 間隔で $3 \mathrm{hr}$ にわたり励起波長 $485 \mathrm{~nm}$, 測定波長 $528 \mathrm{~nm}$ で蛍光強度を測定した。標準物質にはトロロックス (Wako, 細胞生物学用) を用いた。

\section{3.4 過酸化脂質 (LPO)}

LPO は，過剩に生成された ROS によって主に細胞膜 に含まれる脂質が酸化されることによって生じる ${ }^{17)}$ 。本 論文における LPO は, 過酸化脂質の最終生産物であるマ ロンジアルデヒドを分析することによって評価した ${ }^{18)}$ 。 ホモジナイズサンプル $100 \mu \mathrm{L}$ にブチルヒドロキシトル エン $(90 \mu \mathrm{M})$ を $18 \mu \mathrm{L}, 8.1 \% \operatorname{SDS} 45 \mu \mathrm{L}$, チオバビッ ール酸 $(55 \mu \mathrm{M})$ を含み $\mathrm{pH} 3.5$ に調整したトリクロロ酢 酸 $(20 \% \mathrm{v} / \mathrm{v})$ 溶液を $337 \mu \mathrm{L}$ 添加し，よく混合した。こ

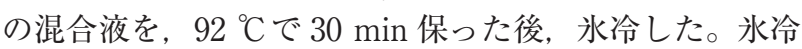
したサンプルを室温に戻し，ブタノール $400 \mu \mathrm{L}$ を添加 し，良く混合した後，遠心した $(4000 \times \mathrm{g}, 10 \mathrm{~min})$ 。上 澄みについて，マイクロプレートリーダを用いて，励起 波長 $530 \mathrm{~nm}$, 測定波長 $560 \mathrm{~nm}$ で蛍光強度を測定した。 標準物質には，1,1,3,3-テトラメトキシプロパン（Wako, 一級）を用いた。

\section{4 統計解析}

酸化ストレスバイオマーカーである CAT, ORAC, LPO の分析は, 1 サンプルにつき 2 回行い, その平均值を分 析結果とした。得られた分析結果は, 対数変換したのち Tukey-Kramer 法により各クラスおよび各採取日時の間 の母平均の検定を行った。ただし，10月 14 日のクラス 3 については，2 サンプルしか採取できなかったため, 平 均值のみを示し, 参考とした。

また，湿重量と各酸化ストレスバイオマーカーとの相 関分析は, ピアソンの積率相関分析により行った。この とき, 各酸化ストレスバイオマーカーは, 全てのサンプ ルデータの平均值と標準偏差を用いて標準化した值を使 用した。ただし，2 クラスしか分類出来なかった 8 月に ついては，相関分析の検討から除外した。

\section{3. 結果・考察}

\section{1 生息量および個体サイズの季節変化}

本研究において，種レベルまでの分類を行わなかった ため, 採取したシマトビケラ属には, 複数種が混在して いる可能性がある。本研究では, 採取したシマトビケラ 属全てについてまとめて検討を行った。定量サンプリン グによって得られた, 各季節の生息密度と湿重量ベース のバイオマスを Table 2 に示す。 2 月や 5 月において, 生息密度および現存量が高いことが示された。また，各 月のサンプルについて, 湿重量について 4 分類したクラ ス毎の個体数を Table 3 に示す。 2 月， 5 月には，湿重 量の小さい個体から大きな個体まで数多く生息していた。 一方， 8 月および 10 月には小さな個体しか確認されなか った。谷田（1980）が夏場の日平均水温が $18{ }^{\circ} \mathrm{C}$ 以下の 山地渓流で調べた研究において, シマトビケラ属のうち ウルマーシマトビケラ (H. tsudai) やギフシマトビケラ (H. gifuana) は，年 1 世代ないし 2 世代で構成され， 5 〜6月に羽化期があると報告している ${ }^{19)}$ 。また, Mackay (1979) は, シマトビケラ属のうち H.betteni, H. Slossonae, H. Sparna が多世代になる条件として, 夏場の高水温と エサ資源が多いことが影響するとしている ${ }^{20)}$ 。本研究の 
Table 2 Density and biomass (Average $\pm \mathrm{SD}$ ) of Hydropsche spp.

\begin{tabular}{ccc}
\hline Date & $\begin{array}{c}\text { Density } \\
\text { individual } \mathrm{m}^{-2}\end{array}$ & $\begin{array}{c}\text { Biomass } \\
\text { g-wet weight } \mathrm{m}^{-2}\end{array}$ \\
\hline \hline $2016 / 2 / 26$ & $197.3 \pm 162.8$ & $3.6 \pm 3.0$ \\
$2016 / 5 / 25$ & $224.0+315.9$ & $3.4 \pm 4.9$ \\
$2016 / 8 / 28$ & $\mathrm{ND}^{*}$ & $\mathrm{ND}^{*}$ \\
$2016 / 10 / 14$ & $35.6 \pm 23.7$ & $0.46 \pm 0.30$ \\
\hline
\end{tabular}

${ }^{*}$ ND: No data

Table 3 Number of individuals for analysis in each wet weight class of Hydropsche spp.

\begin{tabular}{cccccc}
\hline \multirow{2}{*}{ Class } & Wet Weight & \multicolumn{4}{c}{ Number of Individuals } \\
& $\mathrm{x}(\mathrm{mg})$ & Feb .26 & May. 25 & Aug. 28 & Oct. 14 \\
\hline \hline 1 & $6 \leqq \mathrm{x}<12$ & 10 & 12 & 14 & 18 \\
2 & $12 \leqq \mathrm{x}<18$ & 20 & 32 & 10 & 16 \\
3 & $18 \leqq \mathrm{x}<24$ & 13 & 17 & 0 & 2 \\
4 & $24 \leqq \mathrm{x}$ & 21 & 5 & 0 & 0 \\
\hline
\end{tabular}

対象とした流域に接する秩父市内を流れる荒川本流の夏 場の水温は, $24.1{ }^{\circ} \mathrm{C}$ (水文水質データベース, 正喜橋, 2016 年 8 月 3 日）であり, また同日および 8 月の平均気 温はどちらも $26.1{ }^{\circ} \mathrm{C}$ (気象庁, 寄居, 2016 年 8 月 3 日) であった。一般に水温は, 気温と相関があり, また気温 に比べて水温は, 数度低いことが知られている ${ }^{21,22)} 。 ま$ た, 谷田（1980）が対象とした山地渓流は, 河畔林によ って河道が覆われているのに対し, 本研究の対象とした 赤平川は, 河道が河畔林によって覆われているところが 少ない。河畔林によるカバーがある場合, 河畔林による カバーがない場合と比較して水温が低くなることが報告 されている ${ }^{23)}$ 。これらのことから, 本研究の対象とした 赤平川は, 谷田（1980）の対象とした山地溪流よりも水 温が高いと推察される。したがって, 赤平川において採 取したシマトビケラ属についても, 年 1 世代ないし年 2 世代で構成されていると推察され, 特に 5 月のクラス 1 やクラス 2 の個体は, 春先の産卵から成長した非越冬個 体である可能性がある。

Statzner et al. (1999) は, シマトビケラ属の 1 種（H. siltalai）の個体の乾燥重量は湿重量の $16 \%$ 程度であると 報告している ${ }^{24)}$ 。また, 谷田（1980）は, 最終齢期であ る 5 齢幼虫の乾燥重量が H. tudai について 2.5 8 mg 程 度, H. gifuanaについて 5〜22 $\mathrm{mg}$ 程度であることを示 している。本研究で用いたクラス 3 とクラス 4 の乾燥重 量の推定值は, 概ねこれらの範囲内に入る。したがって, クラス 3 やクラス 4 の個体については，5～6月に羽化し て河川から抜け出ており，8月には大きな個体が確認さ れなかったと考えられる。

3.2 個体サイズとストレスバイオマーカーとの関係

湿重量あたりのタンパク保有量は, 8 月および 10 月に おいてクラス間で有意な差が見られなかった（Fig. 2 A)。 一方， 2 月においてクラス 1 は，クラス 2 およびクラス 3 と比較して有意に低く, またクラス 4 は, クラス 3 と 比較して有意に低かった。また， 5 月についても，クラ
ス 1 はクラス 3 と比較して有意に低かった。淡水の二枚 貝について Shetty et al. (2013) は, 個体サイズによっ て, 重量あたりのタンパク保有量が異なることを示して いる ${ }^{25)}$ 。Shetty et al. (2013) によると, 個体サイズが大 きいほど, 乾燥重量あたりのタンパク保有量が多い傾向 にあるものの, 季節によっては中程度の個体の方が大き い個体よりも高いタンパク保有量を持つことも示してい る。このとき, Shetty et al. (2013) は, タンパク保有量 に違いが生じた要因として, 慨条件の違いや生殖サイク ルによる影響があった可能性を指摘している。本研究に おいて対象としたシマトビケラ属についても，季節間の 違いにより，個体サイズによってタンパク保有量に違い が生じたのかもしれない。

抗酸化酵素の 1 つである CAT については, シマトビ ケラ属の大きいクラスほど高い傾向を示し（Fig. 2 B), 2 月と 5 月については湿重量と CAT の間に有意な相関が 見られた (Fig. 3)。酸化ダメージの 1 つである LPO は, 5 月についてのみ大きいクラスほど低い傾向を示した (Fig. 2 D, Fig. 3)。ゼブラフィッシュを対象にし，仔魚 と成魚の 2 段階の比較した研究で, Mu et al. (2015) は, 仔魚と比較して成魚の CAT が高く, LPO が低いことを 報告している ${ }^{10)}$ 。このことから，本研究において対象に したシマトビケラ属の CAT についても, 成長すること で高い值を示した可能性が考えられる。また， 5 月につ いて湿重量の小さい個体でLPO が高いが, 一方の湿重量 の大きな個体については, CAT が高いことから ROSの 発生を抑制することが出来たため, ROSによって生じる 酸化ダメージ14) を抑えることが出来たのかもしれない。 しかしながら, Guerra et al. (2012) がホ夕テ (Argopecten ventricosus）について経時的にCAT や LPO を測定した 際には, 湿重量が高い個体ほどCAT と LPO がともに低 く, 本研究とは異なる傾向を示した ${ }^{26)}$ 。Guerra et al. （2012）の示す CAT と LPO は, 湿重量当たりの值を示 しているため直接的な比較は出来ないものの, 生物種の 
(A)

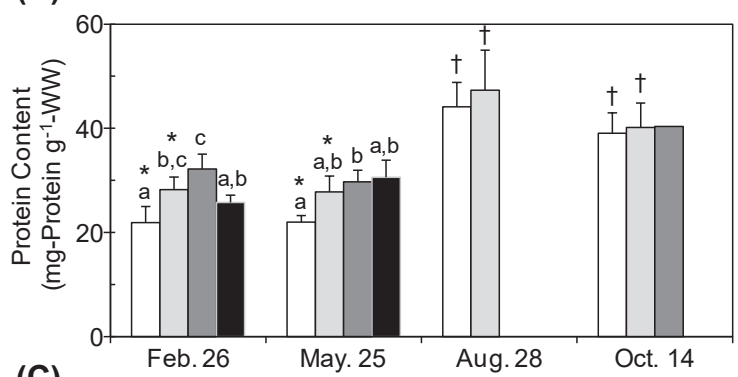

(C)

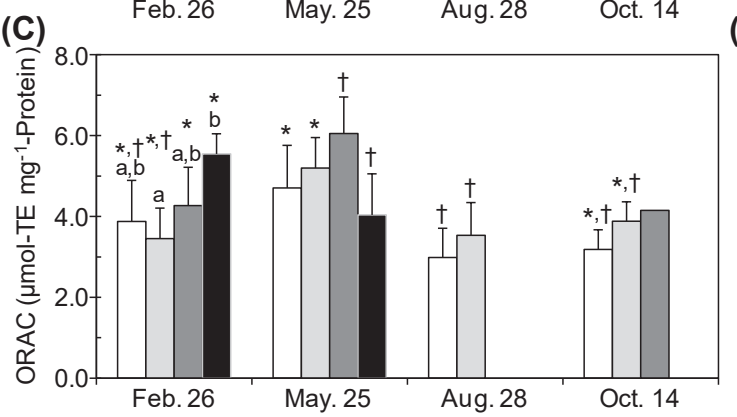

(B)

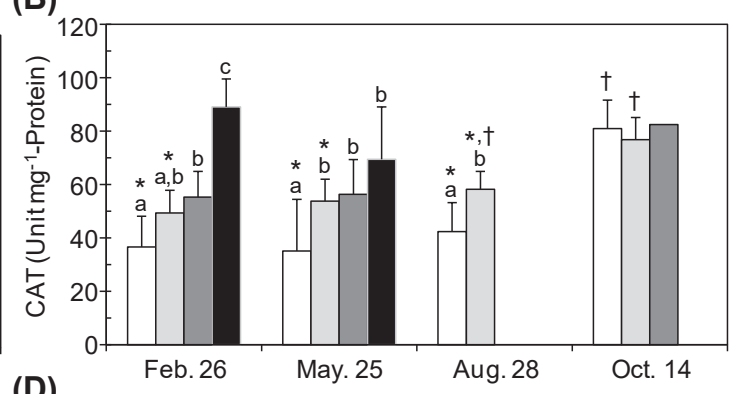

(D)

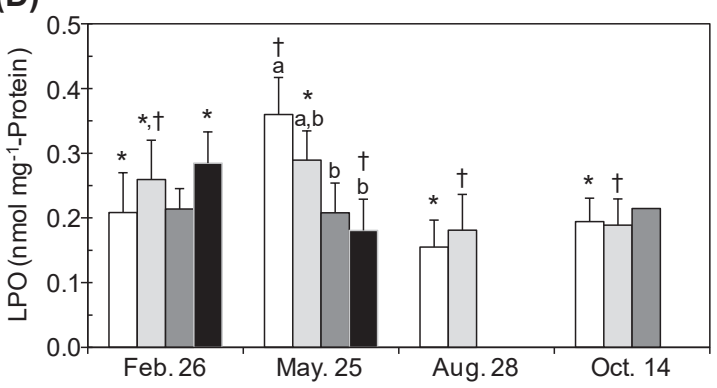

Fig. 2 Seasonal change in (A) protein content, (B) CAT, (C) ORAC, and (D) LPO in whole soft tissue of Hydropsyche spp. Error bars indicate 95\% confidential interval. Different letters indicate significant differences between classes within the sampling date (Tukey-Kramer method, $\mathrm{p}<0.05$ ). Typographical symbols ( ${ }^{*}$ and $\left.\dagger\right)$ indicate significant differences between sampling dates within the class (Tukey-Kramer method, $\mathrm{p}<0.05$ ).

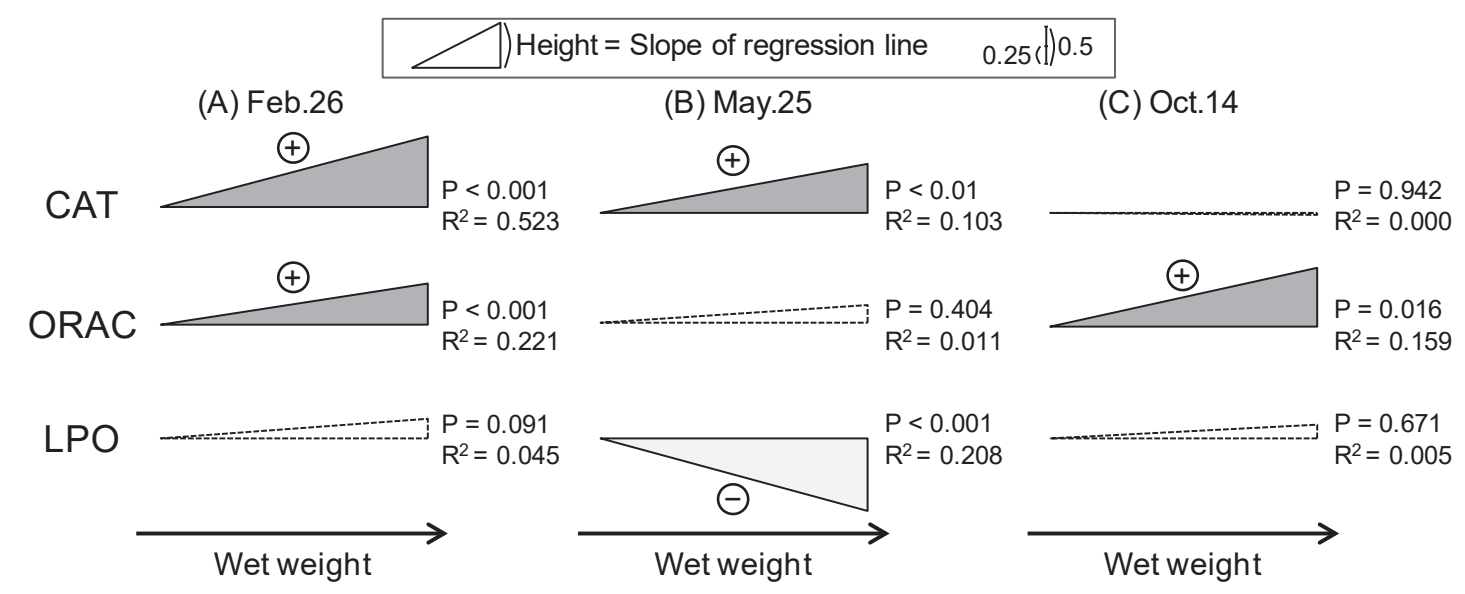

Fig. 3 Correlations between wet weight and standardized oxidative stress biomarker (CAT, ORAC and LPO) in whole soft tissue of Hydropsyche spp. Heights of right angled triangle are the slope of the regression lines. Dark grey triangles indicate positive slope and gray triangles indicate negative value. White triangles with dot lines indicate that there are no significant correlations.

違いによってCATやLPO の応答機構が異なる可能性が 示され，今後さらなる検討が必要であると考える。

生物体内の酸化還元状態の指標とされる $\mathrm{ORAC}^{15)}$ につ いては，シマトビケラ属のクラスによる影響は小さかっ たが (Fig. 2 C), 2月と10月については, 湿重量と ORAC との間に有意な相関が見られた (Fig. 3)。Winston et al. （2004）は，初期発達段階のグラスシュリンプについて, ORAC と類似した原理を用いて分析される TOSCが, 発 達段階が高いほど高い傾向があることを示した ${ }^{27)}$ 。その 他の種について成長と ORAC との応答を調べた研究はな いものの, 本研究においても, 個体サイズの成長ととも
にORACが高い值を示す可能性が示された。谷田（1980） が示すように，シマトビケラ属のうち，H. tudai と比較 して H. gifuana は, 乾燥重量の増加速度や乾燥重量の最 大值が高いこと ${ }^{19)}$ を踏まえると, 湿重量の差に種の違い が影響していた可能性がある。今後は, 種の違いについ ても考慮することによって，より詳細な個体サイズとス トレスバイオマーカーとの関係を明らかにすることが出 来ると考える。

Barata et al. (2005) は, 大型のシマトビケラ属の 1 種 (H. exocellata) の水質污染に対するストレス応答につい ての研究を行っているが, 分析に湿重量 31〜 73 mg の個 
体を使用していた ${ }^{17)}$ 。このとき，抗酸化物質の 1 つであ るCATやGST について, 地点間の有意な差異が見られ たものの, 必ずしも污染の高い地点において応答してい たわけではなかった。本研究で示されるように個体サイ ズに応じた検討を行うことで，より詳細な污染の影響を 検出出来た可能性がある。

\section{3 ストレスバイオマーカーの季節変化}

季節変化については, 全ての時期で採取が可能だった, クラス 1 およびクラス 2 について検討する。タンパク保 有量は，両方のクラスにおいて 2 月および 5 月が概ね 20 〜30 mg-Protein $\mathrm{g}^{-1}$-Wet Weight であったのに対し, 8 月および 10 月が $40 \mathrm{mg}$-Protein $\mathrm{g}^{-1}$-Wet Weight 程度と 有意に高かった（Fig. 2 A)。Shetty et al. (2013) や宮 園・中野 (2000) は, 二枚貝を用いた検討によって, 季 節的なエサ資源の変動や生活パターンによってタンパク 保有量が異なることを示している ${ }^{25,28)}$ 。また, 宮園・中 野（2000）は，ホ夕テ貝がエサ量の豊富な時期にグリコ ーゲンやタンパクを貯蓄することを示しており ${ }^{28)}$, 加え てエネルギー貯蔵物質の消費の際に, グリコーゲンは早 くから消費されるが, タンパクは最終的に利用される物 質とされる ${ }^{29)}$ 。つまり, 赤平川においてシマトビケラ属 の高いタンパク保有量がみられた 8 月と 10 月は, エサ供 給が高く, 体内に十分なエネルギーを貯蓄することが可 能な時期だったかもしれない。

10 月において CAT は, 両クラスともに非出水期と比 較して有意に高い值を示した $($ Fig. 2 B $)$ 。一方, 総抗酸 化力 ORAC や酸化ダメージ LPO は, クラス 1 およびク ラス 2 ともに 5 月においてのみ高い傾向を示した（Fig. $2 \mathrm{C}, \mathrm{D})$ 。これは, 前述の越冬個体および非越冬個体であ る違いが影響したのかもしれない。一般に，造網型のト ビケラの非越冬個体は, 春から夏にかけて急激に成長し, 成虫の個体サイズも越冬個体と比較して小さいことが知

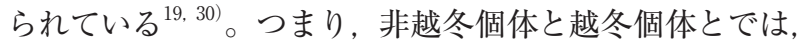
生活史サイクルが異なるため, 摂食によって得たエネル ギーの配分などが異なる可能性がある。例えば，ヒゲナ ガカワトビケラ (Stenopsyche marmorata) の越冬個体 と非越冬個体では, 酵素の一つであるカルボキシルエス テラーゼの含有量が異なることが報告されている ${ }^{31)}$ 。同 様に, 越冬個体と非越冬個体や成長速度の違いが ORAC やLPO の差異に影響した可能性がある。ここで, 出水直 後の調査であった 8 月については, どちらのクラスにつ いても CAT が 2 月および 5 月と同程度であり, また ORACが 2 月および 10 月と同程度であった。CATや ORACによって十分にROS を抑制出来なかった場合に 生じる LPO についても, 低い值を示したことから, 出水 による影響が小さかったと考える。

以上のことから, 河川水生昆虫のうちシマトビケラ属 は, 個体サイズによってストレスバイオマーカーの量が 変動すること, またそれが季節によって異なることが示 された。また, 出水直後でも CAT や ORACの増加が見 られず, LPO も低いことから, シマトビケラ属は, 出水 によるストレスに対する耐性を有する可能性が示唆され た。今後, 本研究において重要性が示された流下有機物 などのエサ条件や脱皮・羽化などを含めた種ごとの生活 史のデータを合わせることで，より詳細なバイオマーカ 一の挙動を把握することができ, 現地において採取した
サンプルに含まれる誤差要因を小さくすることが可能に なるものと考える。

\section{4. まとめ}

本研究では, 河川水生昆虫を対象として, 個体サイズ および季節変動が抗酸化ストレスバイオマーカーに与え る影響を調べた。得られた知見を以下に示す。

1）シマトビケラ属は，概ね湿重量が大きいほど，抗酸 化酵素の 1 つである CAT や生物体内の酸化還元状 態の指標とされる ORACが高い傾向が示された。ま た，その関係は季節によって応答が異なることが示 された。

2）同じサイズラスで比較をしたところ，季節的に変化 することが示された。出水直後であっても, ダメー ジの指標である LPO も低いことから, 出水というス トレスによって生じた ROSを十分に除去する能力を 有していたことが示唆された。

謝 辞

本研究は, 公益財団法人 河川財団の運営する河川基金 の助成（助成番号 28-5311-007）を受けたものである。ま た, 水位データに関しては, 埼玉県秩父県土整備事務所 から提供いただいた。ここに記し，謝意を表する。

（原稿受付 2018 年 5 月 28 日） （原稿受理 2018 年 8 月 9 日）

\section{参 考 文 献}

1) Regoli, F., Nigro, M., Chiantore, M., Winston, G.W., 2002. Seasonal variations of susceptibility to oxidative stress in Adamussium colbecki, a key bioindicator species for the Antarctic marine environment. Science of The Total Environment 289, 205-211.

2 ) Tsangaris, C., Hatzianestis, I., Catsiki, V.A., Kormas, K.A., Strogyloudi, E., Neofitou, C., Andral, B., Galgani, F., 2011. Active biomonitoring in Greek coastal waters: Application of the integrated biomarker response index in relation to contaminant levels in caged mussels. Science of The Total Environment 412-413, 359-365.

3 ) Cruz, D., Almeida, Â., Calisto, V., Esteves, V.I., Schneider, R.J., Wrona, F.J., Soares, A.M., Figueira, E., Freitas, R., 2016. Caffeine impacts in the clam Ruditapes philippinarum: Alterations on energy reserves, metabolic activity and oxidative stress biomarkers. Chemosphere 160, 95-103.

4 ）池田雄, 町田裕貴, 鈴木準平, 藤田昌史, 2016. 都市下水に対 する汽水性二枚貝ヤマトシジミの軟体部と鰓の総抗酸化力の応 答. 水環境学会誌 40(6), 255-260.

5 ) Sala, M., Faria, M., Sarasúa, I., Barata, C., Bonada, N., Brucet, S., Llenas, L., Ponsá, S., Prat, N., Soares, A.M.V.M., CañedoArguelles, M., 2016. Chloride and sulphate toxicity to Hydropsyche exocellata (Trichoptera, Hydropsychidae): Exploring intraspecific variation and sub-lethal endpoints. Science of The Total Environment 566-567, 1032-1041.

6 ) Pradhan, A., Silva, C.O., Silva, C., Pascoal, C., Cássio, F., 2016. Enzymatic biomarkers can portray nanoCuO-induced oxidative and neuronal stress in freshwater shredders. Aquatic Toxicology 180, 227-235.

7 ) Lytle, D.H., Poff, N.L., 2004. Adaptation to natural flow regimes. Trends in Ecology \& Evolution 19(2), 94-100.

8 ) Mensah, P.K., Muller, W.J., Palmer, C.G., 2011. Acute toxicity of Roundup ${ }^{\circledR}$ herbicide to three life stages of the freshwater shrimp Caridina nilotica (Decapoda: Atyidae). Physics and Chemistry of the Earth, Parts A/B/C 36 (14-15), 905-909.

9 ) García, M.E., Rodrígues Capítulo, A., Ferrari, L., 2010. 
Age-related differential sensitivity to cadmium in Hyalella curvispina (Amphipoda) and implications in ecotoxicity studies. Ecotoxicology and Environmental Safety 73(5), 771-778.

10) Mu, X., Chai, T., Wang, K., Zhang, J., Zhu, L., Li, X., Wang, C., 2015. Occurrence and origin of sensitivity toward difenoconazole in zebrafish (Danio reio) during different life stages. Aquatic Toxicology 160, 57-68.

11) Ahmad, I., Mohmood, I., Mieiro, C.L., Coelho, J.P., Pacheco, M., Santos, M.A., Duarte, A.C., Pereira, E., 2011. Lipid peroxidation vs. antioxidant modulation in the bivalve Scrobicularia plana in response to environmental mercury - organ specificities and age effect. Aquatic Toxicology 103, 150-158.

12) Bradford, M.M., 1976. A rapid and sensitive method for the quantitation of microgram quantities of protein utilizing the principle of protein-dye binding. Analytical Biochemistry 72, $248-254$.

13) Cohen, G., Dembiec, D., Marcus, J., 1970. Measurement of catalase activity in tissue extracts. Analytical Biochemistry 34, 30-38.

14) Nonell, S., Flors, C., 2016. Singlet oxygen: Applications in biosciences and nanosciences, Volume.1. Royal Society of Chemistry, London, UK, pp. 1-21.

15) Regoli, F., Winston, G.W., Mastrangelo, V., Principato, G., Bompadre, S., 1998. Total oxyradical scavenging capacity in mussel Mytilus sp. as a new index of biological resistance to oxidative stress. Chemosphere 37, 2773-2783.

16) Suzuki. J., Imamura, M., Nakano, D., Yamamoto, R., Fujita, M., 2018. Effects of water turbidity and different temperatures on oxidative stress in caddisfly (Stenopsyche marmorata) larvae. Science of The Total Environment 630, 1078-1085.

17) Barata, C., Lekumberri, I., Vila-Escalé, M., Prat, N., Porte, C., 2005. Trace metal concentration, antioxidant enzyme activities and susceptibility to oxidative stress in the tricoptera larvae Hydropsyche exocellata from the Llobregat river basin (NE Spain). Aquatic Toxicology 74, 3-19.

18) Knight, J.A., Pieper, R.K., Mclellan, L., 1988. Specificity of the thiobarbituric acid reaction: its use in studies of lipid peroxidation. Clinical Chemistry 34, 2433-2438.

19）谷田一三，1980。貴船川に扔けるシマトビケラ属 3 種の生活史 と分布, 特に生活環の変異と密度と幼虫の成長との関係につい て. 陸水学雑誌 41(2), 95-111.

20) Mackay, R.J., 1979. Life history patterns of some species of
Hydropsyche (Trichoptera: Hydropsychidae) in southern Ontario. Canadian Journal of Zoology 57 (5), 963-975.

21）生田理弘, 大熊孝, 大川秀雄, 神立秀明, 中村一郎, 1991。河 川水温と気温等の相関に関する研究 - 信濃川水系魚野川を例に 一. 水文・水資源学会誌 4(1), 39-45.

22) Harvey, R., Lye, L., Khan, A., Paterson, R., 2011. The Influence of Air Temperature on Water Temperature and the Concentration of Dissolved Oxygen in Newfoundland Rivers. Canadian Water Resources Journal 36 (2), 171-192.

23）中村太士，百海琢司，1989. 河畔林の河川水温への影響に関す 万熱収支的考察. 日本森林学会誌 71(10), 387-394.

24) Statzner, B., Arens, M.F., Champagne, J.Y., Morel, R., Herouin, E., 1999. Silk-producing stream insects and gravel erosion: Significant biological effects on critical shear stress. Water Resources Research 35(11), 3495-3506.

25) Shetty, S., Tharavathy, N.C., Lobo, R.O., Nannu, S., 2013. Seasonal changes in the biochemical composition of freshwater bivalves, Parreysia spp. From Tungabhadra river, Karnataka. International Journal of Pharma Sciences and Research (IJPSR) 4(5), 94-99.

26) Guerra, C., Zenteno-Savín, T., Maeda-Martínez, A.N., Philipp, E.E., Abele, D., 2012. Changes in oxidative stress parameters in relation to age, growth and reproduction in the short-lived catarina scallop Argopecten ventricosus reared in its natural environment. Comparative Biochemistry and Physiology Part A: Molecular \& Integrative Physiology 162(4), 421-430.

27) Winston, G.W., Lemaire, D.G., Lee, R.F., 2004. Antioxidants and total oxyradical scavenging capacity during grass shrimp, Palaemonetes pugio, embryogenesis. Comparative Biochemistry and Physiology Part C: Toxicology \& Pharmacology 139(4), 281-288.

28）宮園章, 中野広, 2000. 北海道オホーツク海沿岸域に打ける地 まきホタテガイの閉殼筋中のタンパク質量とグリコーゲン量の季 節変化. 北海道水産試験場研究報告 58, 23-32.

29）山田茂, 跡見淳子, 富野士良, 原田邦彦, 岩垣丞恒, 渡邊雅 之, 堤達也, 平田耕造, 1990. 運動生理生化学. 培風館, 東京.

30) Nishimura, N., 1966. Ecological studies on the net-spinning caddis-fly, Stenopsyche griseipennis MCLACHLAN (Trichoptera, Stenopsychidae). 1. Life history and habit. Mushi 39, 103-114.

31）林義雄，馬場和彦，1996. 野外におけるヒゲナガカワトビケラ （トビケラ目，ヒゲナガカワトビケラ科）幼虫のカルボキシルエ ステラーゼ活性について． 陸水学雑誌 57(4), 333-336.

\section{[論 文 要 旨 $]$}

ストレス応答物質を用いた環境モニタリングは, 河川での適用例が少ない。河川の生物への適用に際し, ストレス応答物質の自然変動を明らかにすることが重要である。本研究では，河川に生息するシマトビケラ 属の幼虫を対象に，個体サイズと季節変化（2016 年 2 月，5月，8月，10月）がストレス応答物質に与える 影響を調べた。個体サイズは，湿重量に応じて 4 つのクラスに分類した。その結果，抗酸化酵素の 1 つであ るカタラーゼは，大きいクラスほど高い傾向を示した。また，カタラーゼと総抗酸化力は，湿重量との有意 な相関が示された。一方, 同じサイズクラスを対象に季節変化を調べたところ, カタラーゼや総抗酸化力, 酸化ダメージが異なる応答を示した。また, 出水直後の調査であった，8月については，酸化ダメージであ る過酸化脂質が低く，シマトビケラ属は出水によるストレスによって生じた活性酸素種を十分に除去できて いたことが示唆された。

キーワード : 成長段階 ; 季節変化 ; シマトビケラ ; 酸化ストレス 
